\title{
IMPLEMENTASI NEAR FIELD COMMUNICATION (NFC) UNTUK INFORMASI KOLEKSI MUSEUM
}

\author{
Oliver Samuel Simanjuntak ${ }^{(1)}$, Hidayatulah Himawan $^{(2)}$, Muhammad Ali Husaini ${ }^{(3)}$ \\ Program Studi Teknik Informatika, Fakultas Teknologi Industri \\ Universitas Pembangunan Nasional "Veteran" Yogyakarta \\ oliver.simanjuntak@upnyk.ac.id(1), alihusaini95@gmail.com ${ }^{(3)}$
}

\begin{abstract}
People's interest to make the museum as a tourist destination is very low. Therefore, innovations are needed to attract the public interest, and in this case innovation is done in the utilization of NFC technology on android. Currently NFC technology is growing rapidly and has been exploited in various applications, so the utilization of this technology is expected to eliminate the impression of outdated and less attractive to the museum. This application will be divided into two, ie mobile apps for visitors developed using Android Studio software and web applications developed using SublimeText. Mobile apps created to display information from objects in the museum in the form of text, images, video, and audio, by scanning the NFC tag which then the scan results will direct the application to retrieve data from web applications that serve as a server for database management. This mobile app can also display 3600 rooms from every room in the museum. Based on the results of the implementation that has been tested, this application was able to convey information in text, image, sound, or video format by doing a scan on the NFC tag. From user random application feasibility test.
\end{abstract}

Keywords: Android, NFC, Biology Museum, Multimedia Information, Mobile Application

\section{Abstrak}

Minat masyarakat untuk menjadikan museum sebagai tujuan wisata sangatlah rendah. Oleh karena itu diperlukan inovasi untuk menarik minat masyarakat, dan dalam hal ini inovasi dilakukan dalam pemanfaatan teknologi NFC pada android. Saat ini teknologi NFC sedang berkembang pesat dan sudah dimanfaatkan dalam berbagai aplikasi, sehingga pemanfaatan teknologi ini diharapkan dapat menghilangkan kesan ketinggalan jaman dan kurang menarik pada museum. Aplikasi ini akan dibagi menjadi dua, yaitu aplikasi mobile untuk pengunjung yang dikembangkan menggunakan software Android Studio dan aplikasi web yang dikembangkan menggunakan SublimeText. Aplikasi mobile yang dibuat dapat menampilkan informasi dari benda di museum dalam bentuk text, gambar, video, dan audio, dengan cara melakukan scanning pada NFC tag yang kemudian hasil scan tersebut akan mengarahkan aplikasi untuk mengambil data dari aplikasi web yang berfungsi sebagai server untuk manajemen database. Aplikasi mobile ini juga dapat menampilkan ruangan $360^{\circ}$ dari setiap ruangan yang ada di museum. Berdasarkan hasil implementasi yang telah diuji, aplikasi ini ternyata mampu menyampaikan informasi dalam format teks, gambar, suara, maupun video dengan melakukan scan pada NFC tag. Dari uji kelayakan aplikasi oleh pengguna secara acak.

Kata Kunci : Android, NFC, Museum Biologi, Informasi Multimedia, Aplikasi Mobile

\section{PENDAHULUAN}

\subsection{Latar Belakang}

Museum adalah tempat peninggalan benda-benda yang bersejarah, museum juga menyimpan keanekaragaman warisan budaya dan ilmu pengetahuan yang dapat dijadikan sebagai objek wisata edukatif bagi masyarakat dan menjadi bahan studi yang digunakan oleh kalangan akademis, antara lain dengan memberikan sarana informasi yang lengkap serta menyediakan tempat rekreasi yang edukatif, sejarah, dan sumber budaya. Sayangnya minat masyarakat untuk menjadikan museum sebagai tujuan wisata sangatlah rendah.

Seperti yang diungkapkan KRT Thomas Haryonagoro mengatakan, kesan museum di masyarakat selama ini adalah tidak atraktif, tidak aspiratif, tidak menghibur, dan pengelolaan 
seadanya. Keberadaan museum belum mampu menunjukkan nilai-nilai koleksi yang tersimpan kepada public, ungkapnya dalam artikel yang ditulis oleh Yurnaldi (Yurnaldi, 2015).

Pada umumnya di dalam museum, media yang digunakan untuk penyampaian informasi masih menggunakan media konvensional sehingga kurang interaktif dan menarik dalam penyampaian informasi. Informasi yang akan disampaikan menjadi terbatas dan terkesan seadanya sehingga menyebabkan rasa ingin tahu dari pengunjung yang datang juga kecil. Untuk memberikan informasi yang lebih spesifik umumnya dari pihak museum menyediakan Guide atau pemandu untuk menjelaskan setiap informasi koleksi museum, namun kedua penyampaian informasi tersebut masih ada kendala untuk menghadapi masalah tersebut maka museum harus melakukan inovasi menyesuaikan perkembangan zaman saat ini. Salah satunya seperti memanfaatkan teknologi smartphone untuk sistem informasi di museum yang dapat mempermudah pengunjung dalam menerima informasi pada museum dengan jelas karena dengan memanfaatkan teknologi smartphone pengunjung bisa melihat langsung informasi mengenai koleksi di museum tanpa harus menggunakan jasa pemandu. Sehingga diharapkan dengan menggunakan teknologi pengunjung akan lebih lama dalam berkunjung dan tertarik untuk menjadikan museum sebagai tujuan wisata mereka.

Penelitian ini akan memanfaatkan teknologi NFC (near field communication) di dalam penerapannya, seperti : 1). Menggunakan smartphone yang sudah tertanam NFC (near field communication) dan di setiap koleksi museum terdapat nfc tag sebagai scanner, 2). Aplikasi di smartphone dijalankan lalu ditempelkan di NFC tag, 3). NFC Tag akan mengirimkan lokasi (URL) informasi mengenai koleksi yang terdapat dalam museum, 4). Konten tersebut akan dikirimkan ke dalam smartphone pengunjung konten yang dapat diakses oleh pengunjung melalui smartphone berupa teks, gambar, audio, maupun video, 5). Dalam mengambil konten dari server database, aplikasi ini menggunakan bantuan wifi atau jaringan seluler.

Dengan adanya NFC pengunjung dapat memaksimalkan penggunaan smartphone sebagai alat bantu untuk mengidentifikasi benda-benda koleksi museum secara lebih detail. Dengan pemanfaatan teknologi NFC untuk informasi koleksi museum di harapkan mempermudah pengunjung mendapatkan informasi mengenai koleksi museum dengan mudah.

\subsection{Tujuan}

Tujuan dari penelitian ini adalah mengimplementasikan teknologi NFC (Near Field Communication) pada aplikasi layanan informasi koleksi museum berbasis android yang mampu menampilkan multimedia informasi berupa photo, teks, audio, video dan photo 360 tentang koleksi museum. Selain itu menjadi solusi alternatif untuk menggantikan pemandu yang ada di museum untuk Penelitian ini bertujuan menghasilkan aplikasi informasi koleksi benda museum, serta itu untuk meningkatkan pengetahuan tentang informasi yang ada pada museum kepada pengunjung, menumbuhkan rasa ingin tahu wisatawan terhadap informasi koleksi benda museum, adanya inovasi di lingkungan museum dengan pemanfaatan teknologi NFC serta menjadikan bahan pembelajaran interaktif yang menarik.

\subsection{Manfaat}

Manfaat dari penelitian ini yaitu meningkatkan ketertarikan pengunjung untuk mengetahui lebih dalam tentang informasi koleksi benda yang terdapat di dalam museum dan sebagai media pembelajaran yang interaktif bagi pengguna. Bagi pihak pengelola penelitian ini bermanfaat sebagai pengembagan fasilitas museum dan adanya inovasi untuk menarik minat pengunjung.

\section{TINJAUAN PUSTAKA}

\subsection{NFC (Near Field Communication)}

NFC adalah sebuah teknologi terbaru dalam perpindahan data berbasis teknologi RFID (Radio Frequency Identification) yang menggunakan konektivitas tanpa kabel sehingga sangat memungkinkan komunikasi data antar perangkat elektronik dalam jarak dekat menggunakan perantara induksi medan magnet yang terdapat dalam perangkat elektronik tersebut. Teknologi NFC memungkinkan interaksi sederhana dua arah dan aman antara perangkat elektronik yang memungkinkan konsumen atau pengguna untuk melakukan transaksi atau kegiatan lainya 
tanpa kontak, mengakses konten digital, dan menghubungkan perangkat elektronik dengan satu sentuhan. Dengan memanfaatkan elemen kunci dalam standar yang ada untuk teknologi kartu tanpa kontak (contactless). NFC memungkinkan perangkat untuk berbagi informasi pada jarak yang kurang dari $4 \mathrm{~cm}$ dengan kecepatan komunikasi maksimal $424 \mathrm{kbps}$. Pengguna dapat berbagi kartu nama, melakukan transaksi, mengakses informasi dari poster pintar atau memberikan wewenang untuk sistem kontrol akses dengan sentuhan sederhana.

\subsection{Cara Kerja Near Field communication}

Teknologi NFC bekerja dengan sistem transmisi sinyal radio jarak pendek seperti Bluetooth dan Wifi. Perangkat dengan NFC tidak membutuhkan energi listrik yang besar. Ada dua jenis perangkat NFC, satu perangkat tag pasif dan satu lagi perangkat tag NFC pada ponsel. Ketika melakukan kontak, kedua perangkat akan saling terkoneksi dan melakukan pertukaran data dengan frekuensi radio ISM $13.56 \mathrm{MHz}$ dengan maksimum rate transfer $424 \mathrm{Kbps}$. NFC memerlukan dua perangkat untuk berkomunikasi, yang dinamakan NFC Reader dan NFC Tags. NFC Reader adalah Smartphone atau Tablet pengguna dengan fitur NFC. NFC Tag sendiri merupakan terminal kecil berisi sebuah Chip (IC) NFC dengan antena radio terintegrasi. NFC Tag dapat menyimpan berbagai informasi yang ditentukan oleh penggunanya. Pada prinsipnya, kedua perangkat NFC menggunakan medan elektromagnetik untuk melakukan transfer data. Saat kita mendekatkan Smartphone ke Terminal NFC, NFC Reader akan mengaktifkan signal didalam NFC Tag. Lalu kedua perangkat ini langsung berkomunikasi, dimana NFC Reader mengambil informasi didalam NFC Tag. NFC Reader mengirimkan informasi itu ke server, di dalam penggunaan NFC Terdapat 3 mode operasi Yaitu :

a. Tag reader/writer mode Pada mode ini dapat membaca atau menulis data pada NFC Tag

b. Peer to peer mode pada Mode ini memungkinkan dapat bertukar data antar Perangkat NFC yang mendukung. Pada sistem Android mode ini dikenal dengan nama Android Beam.

c. NFC card emulation mode pada Mode ini memungkinkan untuk dapat digunakan layaknya kartu NFC sehingga perangkat NFC daPat diakses oleh NFC reader eksternal.

\section{ANALISIS DAN PERANCANGAN}

\subsection{Arsitektur design}

User yang telah menginstal aplikasi dapat melakukan tapping atau memindai ke NFC tag yang telah disediakan, selain itu user dapat melihat data history hasil scan yang telah dipindai berupa foto dan video. Arsitektur sistem dapat dilihat pada Gambar 1.

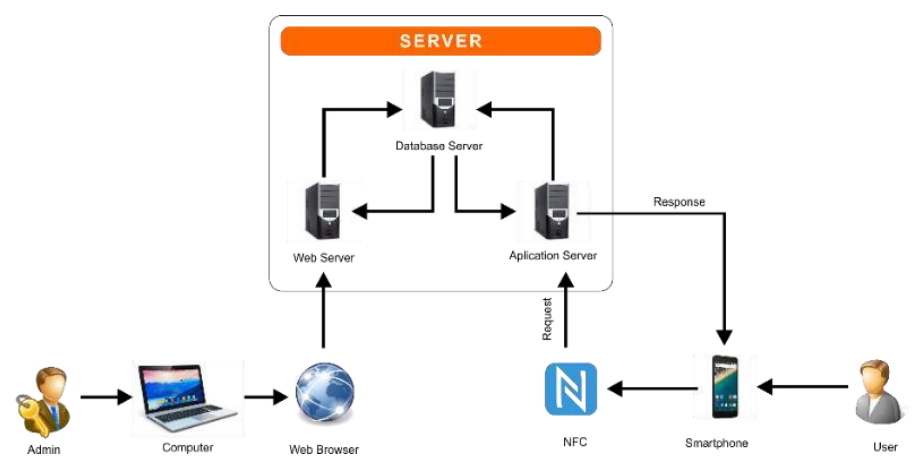

Gambar 1. Arsitektur sistem

Aplikasi ini membutuhkan koneksi internet untuk mengambil data yang ada di server, admin mempunyai hak akses untuk menambahkan data, edit, dan hapus data sedangkan user dapat melakukan tag atau memindai NFC tag. 


\subsection{Rancangan Entity Relationship Diagram (ERD)}

ERD adalah suatu model jaringan yang menggambarkan relasi dan susunan data yang ada di dalam database. Pada perancangan ERD ini pada masing-masing tabel terdapat primary key dan foreign key. Berikut perancangan ERD dijelaskan pada Gambar 2.

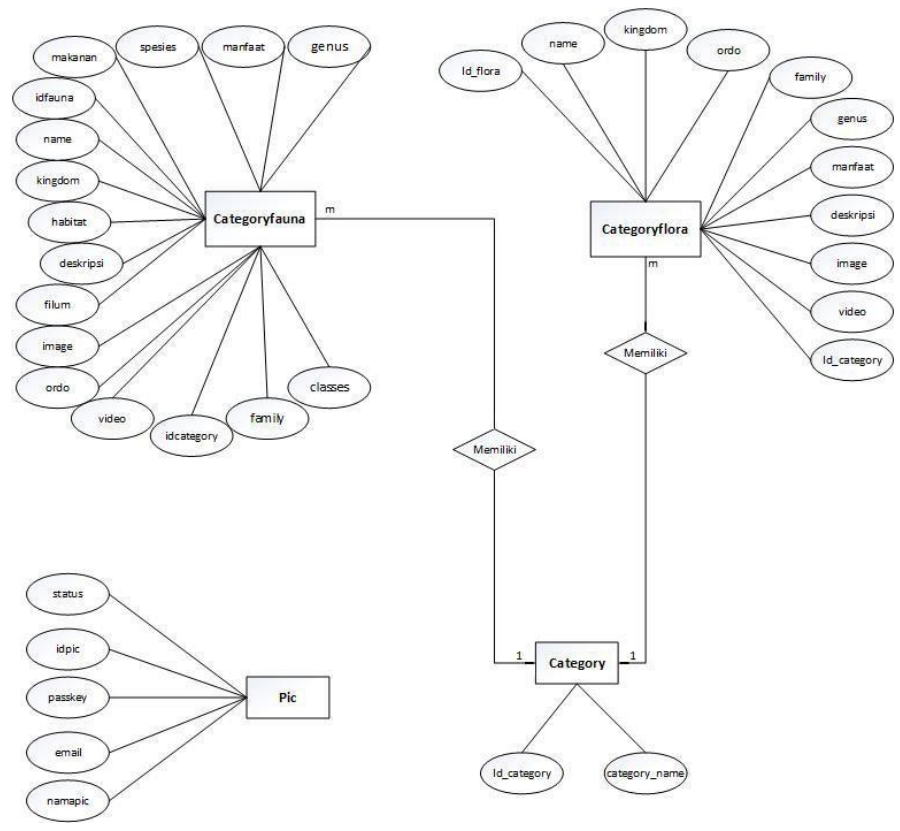

Gambar 2. Rancangan ERD

\subsection{Use Case Diagram Admin}

Pada Tahapan ini akan menjelaskan aksi yang dapat dilakukan oleh admin yang akan digambarkan pada use case diagram pada Gambar 3. Aplikasi ini hanya membutuhkan satu aktor untuk mengoperasikannya.

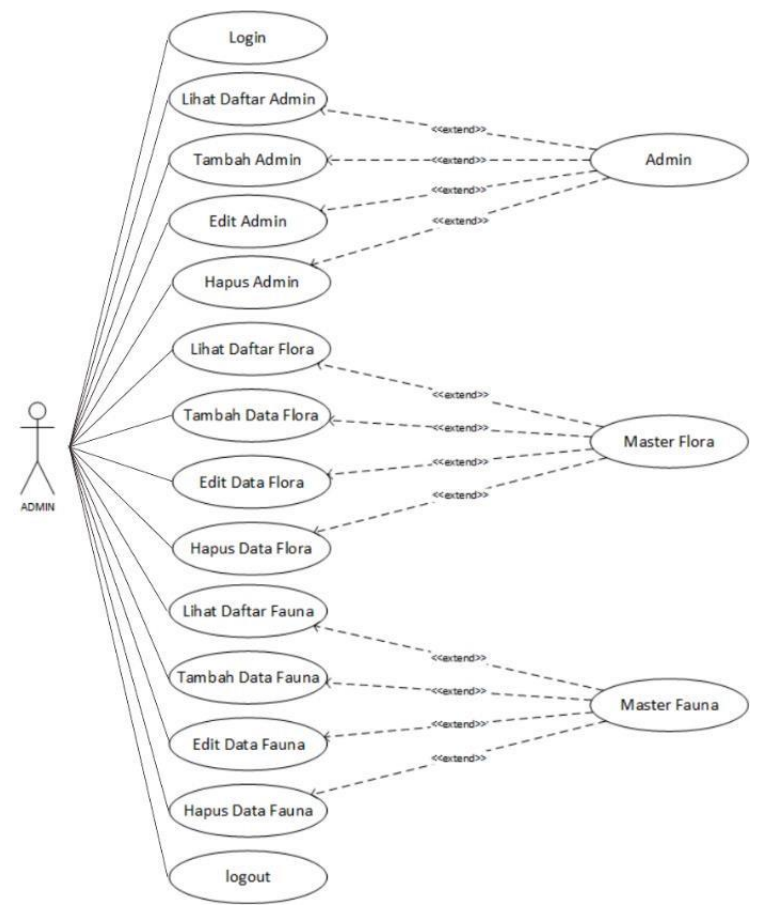

Gambar 3. Use Case Diagram Admin 


\subsection{Use Case Diagram User}

Pada tahapan ini akan menjelaskan aksi yang dapat dilakukan oleh user yang akan digambarkan pada usecase diagram pada Gambar 4. Dalam usecase diagram user dapat melakukan 4 aktivitas utama yaitu memasukan, lihat deskripsi objek, melihat scan history, melihat virtual room, melihat about museum. Aplikasi ini hanya membutuhkan satu aktor untuk mengoperasikannya.

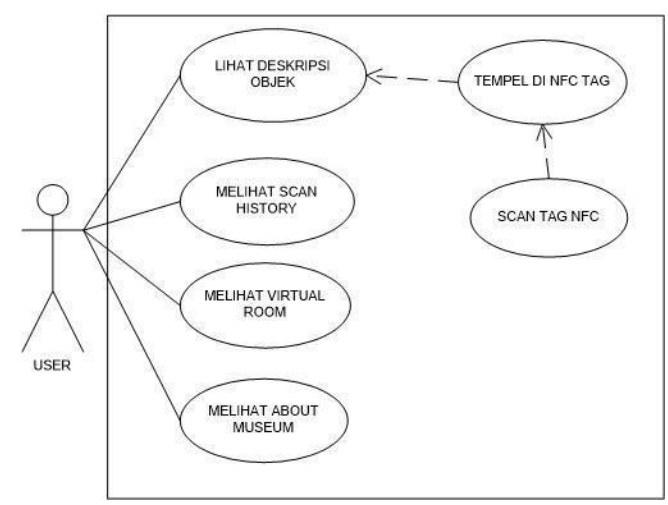

Gambar 4. Use Case Diagram User

\subsection{Activity Diagram Scan}

Pada activity ini user dapat menampilkan menu utama. Activity ini membutuhkan membuka aplikasi, dalam aktivitas ini juga memerlukan controller untuk cek koneksi.

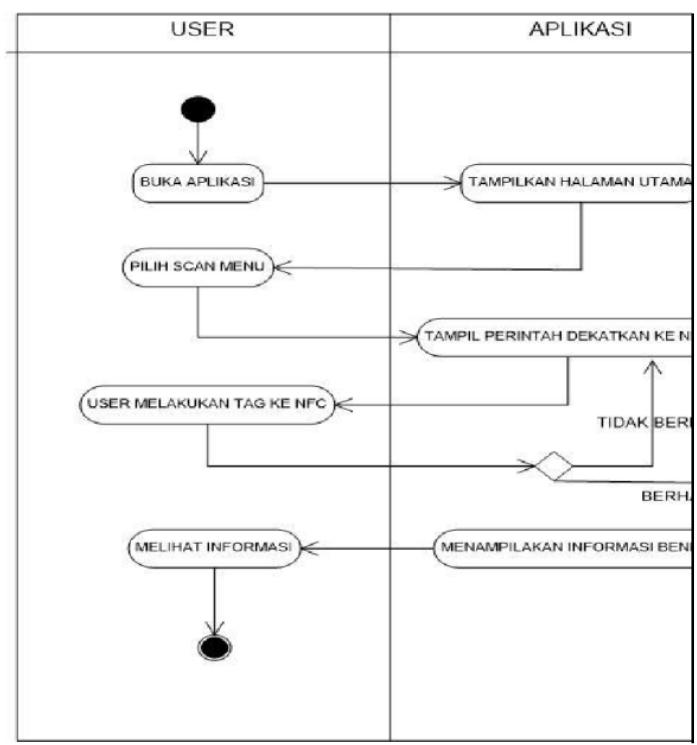

Gambar 5. Activity Diagram Scan

\subsection{Flowchart Pembacaan NFC}

Flowchart pembacaan NFC dari aplikasi sebagai media informasi mengenai detail dari flora maupun fauna yang ada di Museum Biologi dapat dilihat pada Gambar 6, pada program ini dapat disajikan sebagai berikut : 


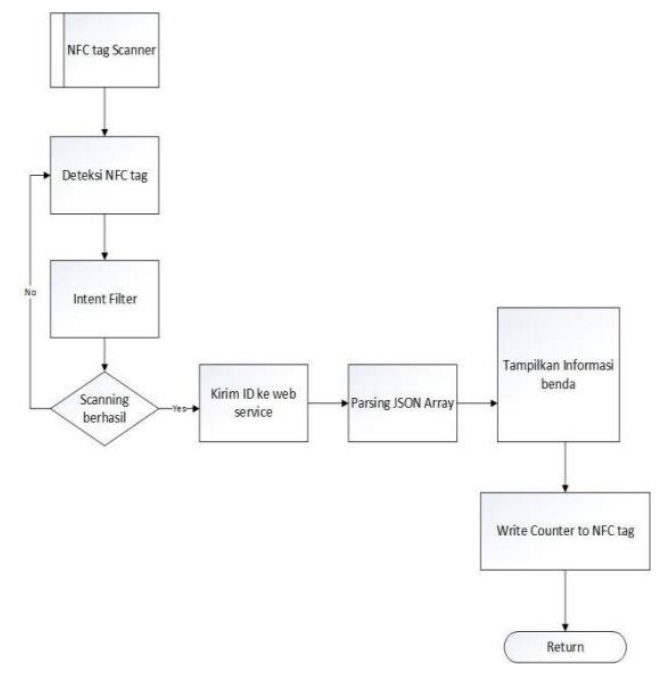

Gambar 6. Flowchart Pembacaan NFC Tag

\section{IMPLEMENTASI}

Halaman launch screen merupakan halaman yang pertama kali saat Aplikasi Android dijalankan. Halaman ini menampilkan logo dari aplikasi museum biologi setelah halaman launchcreen user akan di arahkan ke menu utama, halaman launch screen dapat dilihat pada Gambar 7.

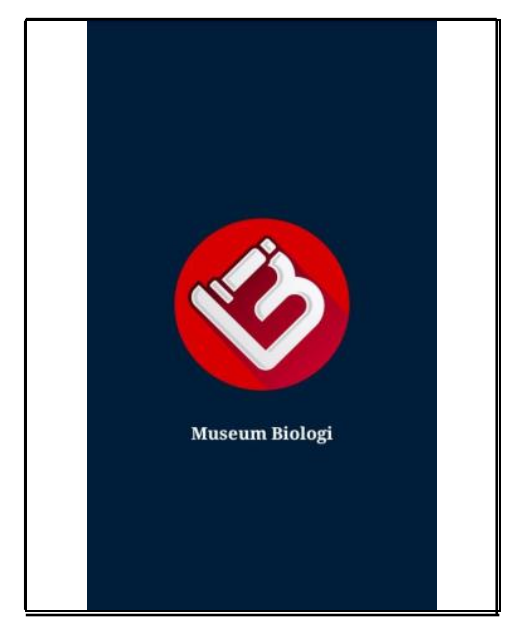

Gambar 7. Halaman Launch Screen

\subsection{Implementasi Halaman Menu NFC}

Halaman menu nfc merupakan halaman untuk melakukan perintah scan ke nfc tag. Pada halaman tersebut terdapat tombol logo nfc yang berfungsi untuk menghidupkan perintah scan. Tampilan dari halaman menu nfc dapat dilihat pada Gambar 8. 


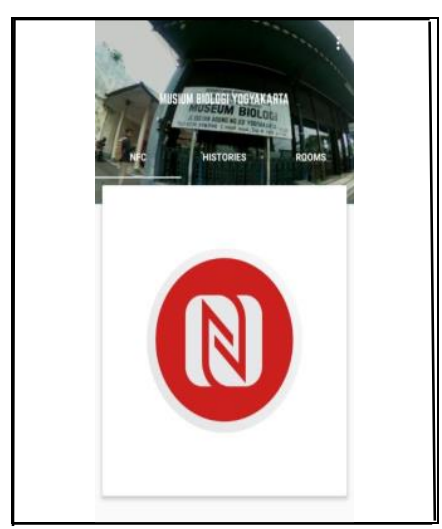

\section{Gambar 8. Halaman Menu NFC}

Halaman histories koleksi museum merupakan halaman untuk menampilkan data hasil scan koleksi museum yang telah berhasil di scan melalui $n f c$ tag. Tampilan dari halaman histories dapat dilihat pada Gambar 9.

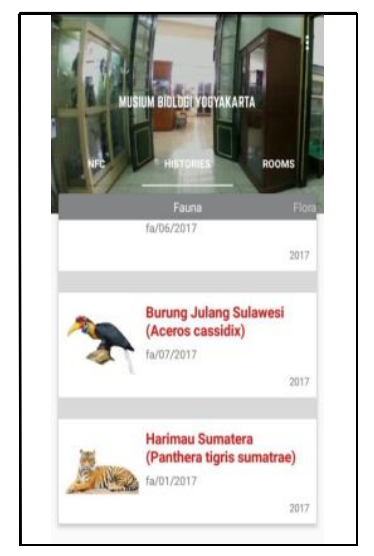

\section{Gambar 9. Halaman Histories Koleksi Museum}

Halaman rooms merupakan halaman yang menampilkan photo panorama virtual reality 360 derajat, halaman ini menampilkan ruangan-ruangan yang ada pada museum, untuk melihat tampilan dari halaman rooms dapat di lihat pada Gambar 10.

Halaman login admin merupakan halaman yang pertama kali saat Aplikasi web service dijalankan.Admin mengisi form dengan username dan password untuk dapat masuk ke menu utama. Tampilan dari halaman login admin dapat dilihat pada Gambar 11. 


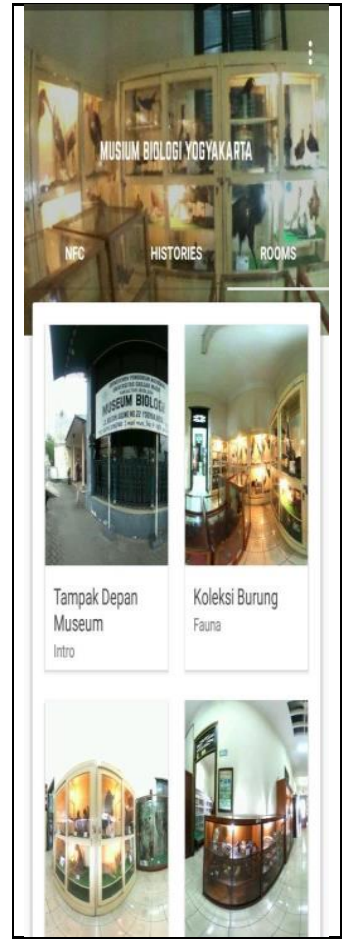

\section{Gambar 10. Halaman Rooms}

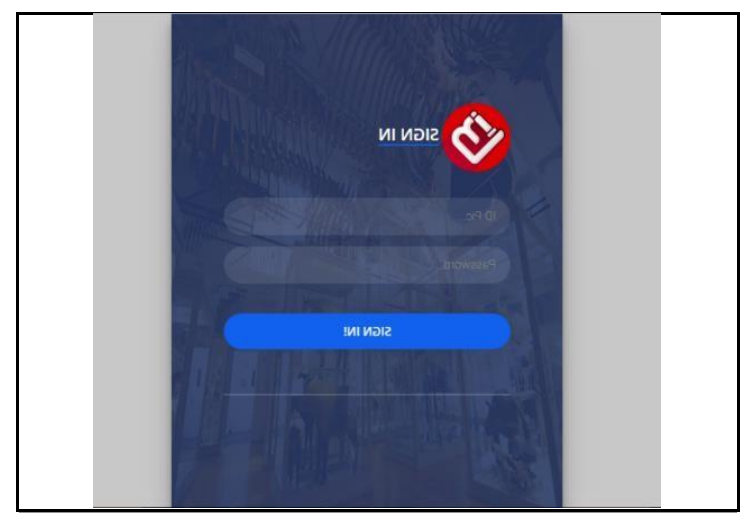

Gambar 11. Halaman Login Admin

\section{KESIMPULAN}

Berdasarkan dari hasil analisis, perancangan dan implementasi yang telah dilakukan sebelumnya, maka dapat dihasilkan sebuah Implementasi Teknologi NFC untuk Informasi Koleksi Museum. Kesimpulan yang dapat diambil dari penelitian ini antara lain:

1. Aplikasi untuk layanan informasi koleksi museum dapat menyampaikan informasi koleksi benda museum berupa text, gambar dan video dengan memanfaatkan teknologi NFC dan dapat menampilkan virtual reality 360 dari setiap ruangan yang ada di museum.

2. Aplikasi tersebut bersifat client dan server yang terdiri dari Aplikasi client (pengguna aplikasi android NFC / pengunjung museum) dan Aplikasi server (admin). Teknologi ini memudahkan pihak museum apabila ada perubahan konten karena informasi yang terdapat di aplikasi mobile terintegrasi dengan server. 
3. Aplikasi bisa menjadi solusi alternatif untuk menggantikan pemandu yang ada di museum untuk menghasilkan aplikasi informasi koleksi benda museum, serta itu untuk meningkatkan pengetahuan tentang informasi yang ada pada museum kepada pengunjung yang berkunjung ke museum.

\section{DAFTAR PUSTAKA}

Akhmad, C. 2014. Menjadikan Museum Tempat Pembelajaran Menyenangkan. dalam internet; http://www.varia.id. Diakses 7 April 2016

G. Gopichand, T. K. Chaitanya and R. R. Kumar, "Near Field Communication and Its Applications in Various Field," International Journal of Engineering Trends and Technology, vol. 4, no. 4, p. 5, April 2013.

Neforawati I, Fareza M.I \& Juniarti V, 2015, Rancang Bangun Aplikasi Sistem Informasi Monitoring Absensi Mahasiswa Politeknik Negeri Jakarta Menggunakan Teknologi NFC (Near Field Communication) Pada Android. Jurnal Politeknologi VOL. 14 No. 2 MEI 2015

Prihartomo, Nyoto dan Sukamto, 2015, Rancang bangun aplikasi pencatatan dan pengolahan data pemakaian KWH digital listrik, aplikasi yang di bangun ini menggunakan teknologi NFC (Near Filed Communication) pada perangkat android, Program Studi Teknik Informatika Universitas Tanjungpura, Pontianak.

Ryan C.W, Hanry N.P dan Djony H.S, P, 2015 Pemanfaatan Teknologi NFC untuk penyampaian informasi multimedia museum mpu tantular, Univesitas Kristen

Petra Surabaya, Surabaya

Salbino Sherif, 2013, Buku Pintar Gadget Android untuk Pemula: untuk pemula, lembar langit Indonesia.

Vidiardi, 2015, pengembangan museum virtual interaktif menggunakan teknologi desktop virtual reality pada museum ranggawarsita, Universitas Teknologi Semarang, Semarang

Yunianto B.W,2014, pemanfaatan teknologi NFC (Near Filed Communication) sebagai sistem informasi pada sengkaling food festifal berbasis web, Univesitas Muhammadiyah Malang, Malang

Yurnaldi \& krt. 2015. Tahun Kunjungan Museum Munculkan New Brand

www.kompas.com/Tahun.Kunjungan.M useum.2015.Munculkan.New.Brand.htm I. Diakses 7 April 2015 